\title{
УПРОВАДЖЕННЯ СПЕЦКУРСУ «МУЛЬТИМЕДІЙНІ ТЕХНОЯОГІЇ В ІСТОРИЧНІЙ ОСВІТІ» В СИСТЕМІ ПІДГОТОВКИ МАЙБУТНІХ УЧИТЕДІВ ІСТОРІЇ
}

У статті автором проаналізовано основні теоретичні положення використання мультимедійних засобів навчання у процесі вивчення історії та представлено головні підходи щодо їх вивчення у процесі викладання спецькурсу «Мультимедійні технологї в історичній освіті». Звернено увагу на відсутність у науцці загальноприйнятої термінології, щцо стосуеться новітніх навчальних засобів, зокрема мультимедійних. Ми проаналізували дослідження вітчизняними та іноземними науковцяяи структури різних типів електронних засобів навчання. У ході цุвого було виявлено, щзо навчальні електронні видання як засоби навчання прийнято вважати електронними засобами навчального призначення, що зберігаються на циифрових або аналогових носіях даних і відтворюються на електронному обладнанні.

Крім того, автором представлено структуру та складові елементи спецкурсу «Мультимедійні технологї в історичній освіті», що надає студентам необхіну науковометодичну інформацію для систематизації та поглиблення знання методик викладання історіі та суспільно-гуманітарних дисциплін, поглиблення загальнотеоретичних іметодичних знань використання технологій мультимедіа, озброєння знаннями про принциии побудови уроків історії. Студенти виконують самостійні практичні та творчі завдання. Підсумковий контроль полягае у виконанні тестових завдань та складання конспектів уроків.

Таким чином, курс «Мультимедійні технологї в історичній освіті» јрунтуеться наміждисциилінарних знаннях, уміннях навичках студентів із дидактики, психологї, методик навчання історії та інших суспільно-гуманітарних дисцииплін та нових інформаційних технологій і технічних засобів навчання. Викладання спецкурсу можливе як в умовах очного, заочного, так $і$ дистанційного навчання за умови оновлення апаратних та програмних засобів мультимедіа для забезпечення високого рівня викладання дисциплін.

Ключові слова: мультимедійні навчальні засоби, мультимедійні технологї, спецякурс, історія, електронні навчальні видання, майбутні вчителі історії.

Постановка проблеми. Активна інформатизація сучасного суспільства та упровадження нових способів комунікації учасників освітнього процесу приводять до необхідності засвоєння новітніх інформаційних технологій ще в процесі професійної підготовки майбутніх учителів. Цьому сприяе упровадження відповідних спецкурсів під час аудиторної та самостійної роботи студентів.

Аналіз досліджень. Активне вивчення питання застосування мультимедійних технологій у навчальному процесі майбутніх вчителів історії дослідили науковці $\begin{array}{lllll}\text { В. Агеєв, } & \text { В. Беспалько, } & \text { В. Биков, } & \text { Б. Гершунський, } & \text { П. Жданович, }\end{array}$ С. Свириденко, Р. Селезньова, А. Шестопалюк (розробка загальних теорій використання мудьтимедіа в освіті); Б. Гершунський, А. Дворецька, Ю. Машбиць, О. Мокрогуз, Д. Чернилевський, М. Шишкіна, П. Фейхі (класифікація різних видів мультимедійних навчальних засобів та суміжних понять); А. Горшков, С. Дмитрієв, М. Жалдак, Ю. Жук, В. Маєр, Р. Томак, В. Шевченко (створення і застосування мультимедійних навчальних програм); О. Мокрогуз, А. Тележинська, С. Телуха (методичні основи використання засобів мультимедіа на уроці історіі).

*C) Гриценко А. П.

us 
Мета статті. Незважаючи на такий рівень наукових досліджень, проблема упровадження спеціальних курсів з вивчення мультимедійних навчальних засобів у процесі професійної підготовки майбутніх учителів історії ще недостатньо досліджена в педагогічній теорії та практиці. Метою статті є визначення оптимадьних складових спецкурсу «Мультимедійні технології в історичній освіті», урахування специфіки використання мультимедіа в процесі навчання історії, предметне вивчення аспектів використання мультимедійних навчальних засобів у процесі вивчення історії.

Викдад основного матеріалу. Завдяки використанню мультимедійних навчальних засобів у процесі університетської історико-педагогічної освіти відбувається формування інформаційно-комунікаційної складовою професійної компетентності студентів-істориків. Утім серед науковців усе ще відсутній окремий напрям дослідження використання інформаційних технологій у наукових історичних дослідженнях, обробки історичної інформації тощо, який ми за аналогією пропонуємо називати «історикокомп'ютерні технології. Дослідник О. Жданович відзначає, що зараз недостатньо розроблені такі теми: орієнтація історика на ресурси, визначення рівня вірогідності та наукової цінності представлених матеріалів, відсутність алгоритмів їхнього аналізу [2, с. 165-166].

У науковий обіг міцно увійшов спеціальний термін «історична інформатика» (Historical Information Science, History and Computing [7]), яка вивчає історичну інформацію та різні шляхи ії створення, зберігання, обробки, вивчення, передавання тощо за допомогою інформаційних (комп'ютерних) технологій. Найбільш перспективними напрямами історичної інформатики, на думку дослідників О. Боонстра, Л.Брьоре, П.Доорна, є моделювання даних, їхня стандартизація; електронна публікація джерел за допомогою технології XML; комп'ютеризований контент-аналіз тексту та аналіз зображень; використання складних статистичних технологій; розробка спеціальних інформаційно-пошукових систем для роботи з історичними даними; 3D-реконструкції, графіка тощо; електронні публікації історичних досліджень, online музейні експозиції [5].

Поряд зі загальновживаним «історична інформатика» до наукового вжитку входить новий термін «Digital history» [6], що перекладається українською «цифрова історія». А. Бородкін вважає, що «терміни History and Computing, Historical Information Science, історична інформатика мають більш широкий зміст, ніж термін Digital history. Адже історична інформатика як частина сучасної історичної науки включає в себе теоретичну компоненту, пов'язану 3 джерелознавчою оцінкою електронних ресурсів, містить аналітичні комп'ютеризовані засоби. Більш прикладна галузь Digital history тісно пов'язана зі застосуванням сучасних цифрових технологій при вирішенні завдань створення історичних ресурсів, оцифрування матеріалів у фондах музеїв, архівів, установ збереження історико-культурної спадщини» [1, с. 20]. Також дослідник Д. Кохен вважає, що «Digital history - це підхід до вивчення та репрезентації минулого, що грунтується на комп'ютерних інформаційних технологіях, інтернеті та спеціальному програмному забезпеченні [6].

Ми згодні 3 думкою В. Кулікова [3], що Digital history передбачає історичні дослідження, які спрямовані на широкі завдання збирання, зберігання, презентації та візуалізації історичної та історіографічної інформації за допомогою інформаційних технологій (віртуальні реконструкції, просторові репрезентації, інформаційні інтернетресурси, інтерактивні гіпермедіатехнологіi), а також створення віртуальних наукових спільнот (collaboratories), «вебдванульних» проєктів тощо. У різних закладах вищої освіти упроваджується відповідний курс, як, наприклад, на кафедрі історичної інформатики Московського держуніверситету (з 2011 р.) та в Київському національному університеті ім. Т. Шевченка, проводяться міжнародні семінари. 
Актуальність уведення спецкурсу «Мультимедійні технології в історичній освіті» до професійної підготовки майбутніх учителів історії не викдикає сумнівів, оскільки майже в усіх освітніх ланках активно впроваджуються дисципліни, які забезпечують успішне застосування інформаційно-комунікаційних технологій, зокрема технологій мультимедіа, тому створення і запровадження нових курсів, зорієнтованих на оволодіння майбутніми учителями історії в закладах загальної середньої освіти історично-комп'ютерними технологіями є вимогою часу. Саме для забезпечення підготовки майбутніх учителів історії до використання технологій мультимедіа у своїй професійній діяльності, а також формування теоретичних знань та навичок практичного застосування мультимедійних навчальних засобів у процесі викладання суспільнометодичних дисциплін у закладах загальної середньої освіти створений спецкурс «Мультимедійні технології в історичній освіті», уведений до навчадьного плану факультету філології та історії Глухівського національного педагогічного університету імені Олександра Довженка у спеціалізації - «Середня освіта (Історія)». Він вивчається в 7-му семестрі та завершується заліком. На вивчення навчальної дисципліни відводиться 36 годин / 1 кредит ЕСTS.

Серед завдань курсу - надання студентам необхідної науково-методичної інформації для систематизації та поглиблення знання методик викладання історії та суспільно-гуманітарних дисциплін, поглиблення загальнотеоретичних і методичних знань із використання технологій мультимедіа на предметах освітньої галузі «Історія»; озброєння майбутніх учителів історії знаннями про принципи побудови уроків історії та суспільно-гуманітарних дисциплін 3 мультимедійною підтримкою; формування вмінь використовувати мультимедійне програмне забезпечення для підготовки та проведення уроків історії, виховних заходів у закладах загальної середньої освіти.

У процесі опанування курсом студенти отримують знання основних тенденцій інформатизації освіти, вимог до вчителя в інформаційному суспільстві, усвідомлюють правила та норм и роботи школярів з комп'ютерною технікою, основні способи використання мультимедійних технологій на уроках суспільно-гуманітарного циклу, дізнаються про вимоги до створення та застосування мудьтимедійних навчадьних засобів на уроках освітньої галузі «Суспільствознавство» в 5-11-х класах закладів загальної середньої освіти.

Пропонований курс поряд із традиційними та практичними заняттями передбачає застосування дистанційних форм навчання. Основний матеріал розміщено на pecypcax Google Classroom, із кожної теми студент має виконати самостійні практичні та творчі завдання та надіслати результати за допомогою названого ресурсу, де й проводився безпосередній аналіз виконання завдань та оцінювання. Підсумковий контроль полягає у виконанні тестових завдань 3 допомогою сервісу Google Forms та складанні конспектів уроків суспільно-гуманітарного циклу (історія, правознавство, громадянська освіта), що також надсилається викладачеві через інтернет у системі Google Клас. Такі форми роботи особливо корисні для заочної форми навчання.

Курс «Мультимедійні технології в історичній освіті» грунтуеться на міждисциплінарних знаннях, уміннях навичках студентів із дидактики, психології, методик навчання історії та інших суспільно-гуманітарних дисциплін та нових інформаційних технологій і технічних засобів навчання. У змісті курсу - два змістові модулі: «Теоретичні засоби використання мультимедіа в історичній освіті (три теми «Можливості мультимедійних технологій у представленні інформації 3 історії та суспільно-гуманітарних дисциплін», «Мультимедіа 3 історії та суспільногуманітарних дисциплін», «Огляд мультимедійних навчальних засобів» та «Методика застосування мультимедійних навчальних засобів на уроках історії та суспільногуманітарних дисциилін» (шість тем, на яких більш грунтовно опановується методика використання електронних підручників та посібників, мультимедійних презентацій 
та електронних історичних, інформаційно-довідкові мультимедійні видання (електронні енциклопедії, галереї, інтернет-ресурси), дитячих ігрових історичних навчальнорозвивальних видань та тестових мультимедійних програм для контродю історичних знань та умінь), а також особливості структури уроків 3 історії та суспільногуманітарних дисциплін у закладах загальної середньої освіти. Складовими курсу є інформаційна, практична частини, контроль і оцінювання. Зокрема, практичну частину призначено для формування вмінь і навичок майбутніх учителів історії користуватися мультимедійними технологіями на уроках із предметів освітньої галузі «Суспільствознавство».

Студентам також пропонуеться чіткий алгоритм підготовки мультимедійних матеріалів, критерії відбору мультимедійної інформації та оцінювання мультимедійних фрагментів до уроків освітньої галузі «Суспільствознавство», алгоритм підготовки та вимоги до презентації в програмі PowerPoint, тестів сервісу Google Форми, використання можливостей сервісу Google Клас, вимоги до створення мультимедійних тестів для контродю знань.

Успішне викладання дисципліни вимагає використання певних методів як загальнодидактичних, так і спеціальних методів навчання історії та суспільногуманітарних дисциплін, модифікованих з урахуванням особливостей мультимедійних технодогій. Передбачається, що важдиву роль відіграє самостійна робота студентів.

На лекціях спецкурсу «Мультимедійні технології в історичній освіті» домінуе пояснювально-ілюстративний репродуктивний дидактичний метод, який забезпечуе засвоєння змісту курсу. Студенти отримують стислі теоретичні відомості про виникнення і сутність поняття «мультимедіа», «мультимедійні навчальні засоби», основні принципи організації мультимедійних навчальних засобів 3 суспільногуманітарних дисциплін, програмні та апаратні засоби мультимедійних технологій 3 історії. Крім того, вивчаються можливості технічних мультимедійних засобів у представленні історичної інформації. Важливе місце на лекціях посідає класифікація мультимедійних навчальних засобів суспільно-гуманітарного циклу в закладах загальної середньої освіти.

Пояснювально-ілюстративний метод завжди вимагає поєднання усного пояснення 3 демонструванням, ілюстрацією зразків та прикладів, оскільки це сприяе актуалізації навчального досвіду студентів, сприяе розвитку їхньої пізнавальної активності. До лекцій курсу включено значну кількість наочно-демонстраційного матеріалу.

Проблемно-пошуковий метод у вивченні курсу «Мультимедійні технології в історичній освіті» застосовуеться в підготовці до практичних занять та в організації самостійної роботи студентів. Він реалізовується у визначенні проблемних запитань, створенні проблемних ситуацій, вирішення яких обговорюеться студентами разом із викладачем для подальшого самостійного пошуку. Наприклад, під час вивчення теми «Особливості застосування дитячих ігрових історичних навчально-розвивальних видань» викладач ознайомлює студентів із кількома мудьтимедійними навчальними засобами для учнів. Студенти розглядають ігрові мультимедійні програми (екшени, шутери, аркади, спортивні, квести, рольові, перегони, симулятори, логічні, пригоди, стратегіі) на історичну тематику: «Вікторія», «Епоха імперій», «Хрестоносці», «Европа», «Рим», «Козаки», «Помпеї», «Корсари», «Цивілізація», «Світ військових дітаків», «Протистояння», «100 років війни», «Історія імперій», «Дипломатія». При цьому педагог звертає увагу, що деякі завдання й історичні ігри 3 цих програм майже точно повторюються i пропонуе для самостійного опрацювання завдання: докладно проаналізувати названі ігри; знайти спільні й відмінні риси в їхньому змісті й структурі; 3'ясувати, які саме завдання пропонуються для контролю історичних знань і умінь.

Крім того, увага студентів концентрується на використанні комп'ютерних відеоігор на історичну тематику, які опосередковано (в ігровій формі), візуально 3 допомогою 
реальних історичних персонажів, пейзажів, інтер'єрів, військової техніки, «занурюють» учасників у ті чи інші історичні події, що передбачає володіння певним багажем історичних знань («Assassin's Creed», «Europa Universalis», «Crusader Kings 2», «Total war», «Mount and blade). Вони підвищують інтерес до навчання історії, стимулюють розумові процеси і сприяють довгостроковому запам'ятовуванню історичного матеріалу.

Для успішного засвоєння спецкурсу «Мультимедійні технології в історичній освіті» до самостійної роботи студентів залучається метод творчих завдань, що потребують від учнів творчої діяльності, самостійного пошуку способів вирішення творчого завдання, уміння використати набуті знання в нових умовах, створити щось суб'єктивно чи об'єктивно нове [4, с. 155]. Серед них доцільно виділити демонстрацію прикладів електронних підручників і посібників (ЕП) 3 історії та суспільно-гуманітарних дисциплін у закладах загальної середньої та вищої освіти; презентацію фрагментів уроків історії та виховних заходів 3 використанням мудьтимедійної презентації у програмі Power Point iз застосуванням інтерактивних прийомів роботи, а також навчально-історичних комп'ютерних ігор, розважальних історичних відеоігор (стратегій); обговорення позитивних та негативних аспектів запропонованих фрагментів уроків; демонстрація використання можливостей електронної енциклопедії, віртуального музею 3 презентацією фрагменту уроку історії 3 використанням можливостей Вікіпедії та її сестринських проєктів тощо.

При цьому бажано, щоб студенти дотримувалися алгоритму підготовки мультимедійних матеріалів до уроків суспільно-гуманітарного циклу: визначення теми, мети, типу та очікувані результати уроку; складання орієнтовної структури уроку у відповідності з метою; продумування етапів, на яких необхідно залучити засоби мультимедіа 3 аналізом доцільності їх застосування в порівняні 3 традиційними засобами.

Висновки. Отже, упровадження спецкурсу «Мультимедійні технології в історичній освіті» до університетської підготовки вчителів історії дозводяе подолати протиріччя, які й донині існують у навчанні учителів історії: між високими вимогами сучасної історичної педагогіки, які висуваються до історико-комп'ютерних технологій, і низьким реальним рівнем використання комп'ютерних, зокрема мультимедійних, засобів на уроках історії та в позакласній роботі в закладах загальної середньої освіти. Перелік мультимедійних програм 3 історії та суспільно-гуманітарних дисциплін, які пропонуються студентам для опрацювання візуальних та аудіальних даних під час вивчення спецкурсу, варто постійно оновлювати 3 урахуванням стрімкого розвитку сучасного ринку апаратних та програмних засобів мультимедіа для забезпечення високого рівня викладання дисциплін освітньої галузі «Суспільствознавство» в закладах загальної середньої освіти.

Викладання спецкурсу можливо як в умовах очного, заочного, так і дистанційного навчання: усі складові дисципліни розташовані на ресурсі Google Клас, консультації викладача в достатньому обсязі забезпечуються електронним листуванням через пошту або через названий ресурс, а також 3 допомогою організації конференцій на платформі Zoom. В умовах неухильного розвитку мультимедійних технологій питання якісного методичного та дидактичного упровадження спецкурсу $є$ перспективним ддя подальшого наукового пошуку.

\section{Список використаних джерел:}

1. Бородкин $И$.И. Digital history: применение цифровых медиа в сохранении историкокультурного наследия? Историческая информатика. Информационные технологии и математические методы в исторических исследованиях и образовании. 2012. № 1. С. 14-21.

2. Жданович О. Історіографічні аспекти наукової інформатики. Спеціальні історичні дисцииліни: питання теорії та методики. 2005. № 12. С. 154-168.

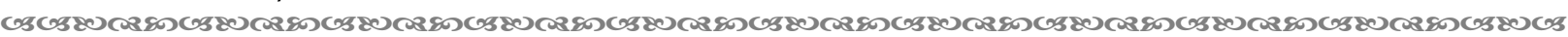
102 
3. Куліков В. О. Digital history: становлення, сучасний стан, перспективи. Спеціальні історичні дисичиліни. 2013. № 21. С. 27-44.

4. Унт И. Э. Индивидуализация и дифференциация обучения. М. : Педагогика, 1990. 192 с.

5. Boonstra O., Breure L., Doorn P. Past, Present and Future of Historical Information Science. Amsterdam, 2004. URL: http://www.niwi.knaw.nl/nl/geschiedenis/onderzoek/onderzoeks projecten/past present future of historical information science/new/

6. Cohen D., Rosenzweig R. Digital History: A Guide To Gathering, Preserving, and Presenting the Past on the Web. Philadelphia, 2005. 328 p.

7. McCrank L. J. Historical Information Science: An Emerging Unidiscipline. New Jersey, 2001.

\section{References:}

1. Borodkin, L. I. (2012). Digital history: primenenie cifrovyh media v sohranenii istoriko-kul'turnogo naslediya? [Digital history: the use of digital media in the preservation of historical and cultural heritage?]. Istoricheskaya informatika. Informacionnye tekhnologii i matematicheskie metody $v$ istoricheskih issledovaniyah i obrazovanii, 1, 14-21 [in Russian].

2. Zhdanovych, O. (2005). Istoriohrafichni aspekty naukovoyi informatyky [Historiographical aspects of scientific informatics]. Spetsial'ni istorychni dystsypliny: pytannya teoriyi ta metodyky, 12, 154-168 [in Ukrainian].

3. Kulikov, V. O. (2013). Digital history: stanovlennya, suchasnyy stan, perspektyvy [Digital history: formation, current state, prospects]. Spetsial'ni istorychni dystsypliny, 21, 27-44 [in Ukrainian].

4. Unt, I. E. (1990). Individualizaciya $i$ differenciaciya obucheniya [Individualization and differentiation of education]. Moscow: Pedagogika [in Russian].

5. Boonstra, O., Breure, L., \& Doorn, P. (2004). Past, Present and Future of Historical Information Science. Amsterdam. Retrieved from http://www.niwi.knaw.nl/nl/geschiedenis/onderzoek/ onderzoeksprojecten/past present future of historical information science/new/ [in English].

6. Cohen, D., \& Rosenzweig, R. (2005). Digital History: A Guide To Gathering, Preserving, and Presenting the Past on the Web. Philadelphia [in English].

7. McCrank, L. J. (2001). Historical Information Science: An Emerging Unidiscipline. New Jersey [in English].

\section{IMPLEMENTATION OF THE SPECIAL COURSE "MULTIMEDIA TECHNOLOGIES IN HISTORICAL EDUCATION" IN THE SYSTEM OF TRAINING OF FUTURE HISTORY TEACHERS}

In this article the author analyzes the main theoretical principles of the use of multimedia learning tools in the process of history study and presents the main approaches to their study in the course of teaching the course "Multimedia Technologies in Historical Education". Attention is drawn to the lack of conventional terminology in science regarding the newest teaching aids, in particular multimedia. We have analyzed studies by domestic and foreign scholars on the structure of different types of e-learning tools. In the course of this, it was found that educational electronic publications, as a means of learning, were considered to be electronic educational tools. This happens if they are stored on digital or analog storage media and played on electronic equipment.

In addition, the author presents the structure and components of the special course "Multimedia Technologies in Historical Education", which provides students with the necessary scientific and methodological information to systematize and deepen the knowledge of teaching methods of history and social and humanitarian disciplines, the deepening of general theoretical and methodological technologies, equipping them with knowledge of the principles of history lessons. Students complete independent practical and creative tasks. The final control is to complete the test tasks and compile lessons.

Thus, the course "Multimedia Technologies in Historical Education" is based on interdisciplinary knowledge, skills of students in didactics, psychology, teaching methods of history and other social sciences and humanities and new information technologies and technical means of teaching. Teaching of the special course is possible both in terms of full-time, distance and distance

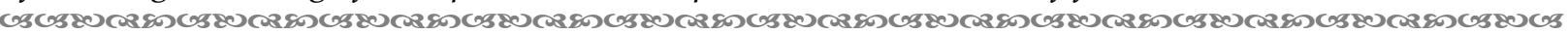


learning, provided the updating of multimedia hardware and software to ensure a high level of teaching of the disciplines.

Key words: multimedia educational tools, multimedia technologies, special course, history, electronic educational publications, future history teachers.

Дата надходження статті: 20.01.2020 p. Рецензент: доктор педагогічних наук, професор Курок В. П.

УДК 59.947.5:37:140.8:[378:37.091.12:5-051]:122 (045)

DOI https://doi.org/10.37915/pa.vi45.88

Колесник М. О. orcid.org/0000-0003-0775-4035

\section{СТАНОВЯЕННЯ ПРИЧИННО-СИСТЕМНОГО СВІТОГЛЯДУ МАЙБУТНЬОГО ВЧИТЕЛЯ ЯК ОСНОВА ФОРМУВАННЯ НАУКОВОЇ КАРТИНИ СВІТУ}

У статті розглянуто питання становлення наукового світогляду на основі причинносистемного підходу, що складае основу у формуванні універсальної наукової картини світу майбутніх учителів природничих спеціальностей. Проаналізовано дискусійні думки, останні дослідження щодо становлення наукового світогляду студентів вищих педагогічних навчальних заходів. Розкрито суть світоглядних понять, що складають вісь дидактичного ядра моделі формування універсальної картини світу індивіда. Дається визначення поняття «природопричинність», яким пояснюеться приналежність поняття до категоріі світоглядного. Охарактеризовані основні універсальні закономірності (доцільність, системність та інтеграція, єдність, різноманіття, узаємопов'язаність, універсальність, системоутворення), дидактичні умови дидактичного резонансу, формування дидактичних атракторів, дидактичної контамінації, дидактичної збалансованості диференціаціиі та інтеграції в змісті освіти та дидактичного моделювання та проєктування, щяо складають дидактичне ядро моделі формування універсальної наукової картини світу та визначені основні категорії світоглядних понять на прикладі природничо-наукової складової змісту освіти. Представлені експериментальні дані локальних експериментів щодо впливу запропонованої методологічної концепції та методичного підходу у формуванні світоглядних понять на рівень теоретичного мислення студентів стариих курсів природничих спеціальностей педагогічних закладів вищої освіти. В аргументації дидактичних положень ураховуються положення теорії розвитку понять та пропонуються рівні причинносистемного узагальнення - ієрархічно-системний, який дозволяе фрактальну аналогію поняття за рівнями організації матерії, та образно-символічний. Пропонуеться спосіб формування світоглядних понять за допомогою універсального алгоритму законів природи.

Ключові слова: дидактичне ядро, світоглядні поняття, універсальна наукова картина світу, дидактичні умови, причинно-системний підхід.

Постановка проблеми. Перед сучасною освітою постає завдання сформувати еводюційний, причинно-системний світогдяд усіх суб'ектів освіти. Ми спираємось на визначення: причинно-системний світогляд як система погдядів, оцінок та образних уявлень про світ, яка обгрунтована $з$ точки зору причинно-системних зв'язків на основі всезагальних універсальних законів природи, водночас $є$ динамічною системою концептуальних утворень як результату попереднього досвіду дюдини, що детермінуе спосіб сприйняття, інтепретації та категоризації світу, а також визначає стратегії і тактики взаємодії людей, колективів, суспільних інститутів. Убачаємо певну

*C) Колесник М. O.

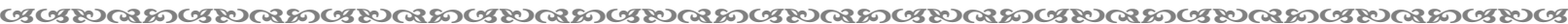

